\title{
Students' Errors in Using Adjective Clause of Writing Descriptive Paragraph at Writing Class I of English Department of STKIP PGRI West Sumatera
}

\author{
Elmiati \\ English Department, STKIP PGRI Sumbar \\ elmiatisofiana@yahoo.com
}

\begin{abstract}
Penelitian ini bertujuan untuk melihat kesalahan-kesalahan mahasiswa dalam menggunakan adjective clause. Penelitian ini adalah penelitian descriptif yang dilaksanakan di kelas Writing I Pendidikan Bahasa Inggris STKIP PGRI SUMBAR. Yang terdiri dari 39 orang mahasiswa. Data penelitian dikumpulkan dengan menggunakan tes menulis paragraph descriptive . Kemudian semua data dianalisa dengan analisa deskriptif untuk mengetahui kesalahan-kesalahan dalam menggunakan adjective clause pada menulis paragraph deskriptif.. Temuan dalam penelitian ini menunjukan bahwa kesalahan yang dominan muncul dalam menulis adalah pada penggunaan adjective clause sebagai pengganti subjek dan objek dari kata kerja.
\end{abstract}

Keywords - Students' errors, adjective clause, descriptive paragraph

\section{INTRODUCTION}

Writing is one of the four skills that should be mastered by the students. In writing they have to consider several things to make the readers understand their ideas. Weather it is related to vocabulary or words choice, content, coherence, cohesion, and grammar or structure. However, grammar has big roles in writing. So the readers will understand if the sentences consist of good grammar.

In writing descriptive paragraph, the students use many kinds of sentence forms. One of them is adjective clause. Adjective clause is a clause that modifies noun or pronouns. An adjective clause usually comes immediately after the word (s) it modifies. The errors of using adjective clause in writing influence the process of constructing descriptive paragraphs, because a writer also use it to express her ideas. It can also determine good or bad her writing. If they do not master the use of adjective clause, they will construct wrong descriptive paragraph.

Students, who take writing 1 at English Department of STKIP PGRI West Sumatera write descriptive paragraph. In descriptive paragraph they use some adjective clauses, such as relative pronoun (who, whose, which, whom, and that).
For constructing descriptive paragraph, there are some errors which are found such as adjective clause, noun clause, adverb clause, using articles and preposition.

Consider to the phenomena above, the researcher interested to investigate the student's error of using adjective clause in writing descriptive paragraph. She found many students can not use appropriate adjective clause in their writing. For example, they can not use relative pronouns (who, whose, which, whom and that) into adjective clause correctly.

In this research, it is necessary for the researcher to limit her research on students' errors in using adjective clause in writing descriptive paragraph. They are replacements of subject, replacement of object of verb, replacement of preposition and replacement of possessive.

\section{Review of The Related Literature}

\section{Adjective Clause}

Bonner (1999:238) defines that adjective clause is a dependent clause that modifies as noun or pronoun. It describes, identifies, or gives further information about noun. An adjective clause usually comes immediately after the word (s) it 
modifies. In some cases, a pronoun or prepositional phrase may come between noun and clause.

Then, Walter (2000: 276) states that in adjective clause, a full subject and predicate is changed by means of special introductory words which has the same referent as the preceding noun or pronoun. The form and position of this introductory word subordinates the adjective clause to a main clause.

However, Walter (2000:324) states that there are five usages of adjective clause. They are replacement of subject, object of verbs, possessive, and object of prepositions. The following explanation discuss about them.

\subsection{Replacements of subject}

An adjective clause is called replacement of subject or object of the main clause is the same as subject of dependent clause (second sentence). We use relative pronoun "who" or "that" to indicate person and "which" or "that" to indicate ideas and things.

For example:
a. The boy is my son
b. He is wearing brown jacket

The boy is my son = an independent clause

Who is wearing brown jacket
$=$ Adjective clause

\subsection{Replacement of Object of Verbs}

An Adjective clause is called replacement of object of verbs if a noun (subject or object) in the main clause is the same as object of the second of the second sentence (dependent clause). We use the relative pronouns "who" $(\mathrm{m})$ or that to indicate the person and we use relative pronouns "which" or "that" to indicate things. We also can use "where" to indicate place and "when" to indicate time. For example:

a. Whom, that

The man was doctor Haryadi

I met him in the hospital

The man whom I met yesterday was doctor Haryadi. b. Which

The bag was expensive

I bought it last year

The bag which I bought last year was expensive

c. Where and when

The house is new

Mr. Joko lives there.

The house where Mr. Joko lives is new.

\subsection{Replacements of possessive}

The relative pronoun (whose) can replace a possessive. Whose indicate to place, ideas, or things. For example:

I was glad to meet Mr. John

He shared about his experience

I was glad to meet Mr. John, whose shared about his experience.

\subsection{Replacement of object of prepositions}

An adjective clause is called objects of prepositions if a noun (subject or object) of the first sentence (main clause) is the same as object of preposition of the second sentence (dependent clause)

For example:

She is my cousin

I tell you about her

She is my cousin whom I tell you about (informal) or

She is my cousin about whom I tell you (formal)

\section{Writing}

Writing is one of four skills in English. The product of writing is produced after doing some processes. Those processes happen again and again until writer creates a good writing. Hemingway in Oshima (1991:3) states that writing is a process, not a product. It means that a piece of writing is looked from the process that has been done. We should have more attention on the process than product that will be produced.

Furthermore, Halliday in Nunan (2000:84) explains that writing has evolved in societies as a 
result of cultural changes creating communicative needs which can not be readily met by spoken language. Societies that can not speak directly, they can write their message that will be told others. So, they have no challenging their social reality.

Then, Sokolik in Linse (2003:98) states that writing is combination of process and product. The process refers to the act of gathering ideas and working with them until they are presented in a manner that is polished and comprehensible to the readers. The process is influences the product that has been created. So that, writing is activity to share our ideas that is combined between process and product. They have relation each others. The process how to create a good wring is important to create a good writing.

Based on the explanation above, it can be concluded that writing is an activity to explore our ideas into a piece of paper. It is a combination of process and product. The process is necessary to produce a product. The process is particular way in generating ideas and the product is the result of the process. Moreover, writing is not only focusing on exploring ideas but also in arranging sentences into a good paragraph.

\section{Process of Writing}

There are some steps in writing activity. The steps help us in this activity. Oshima (1991;3) states some steps in writing process, they are:

a. Pre-writing.

In this stage the writer chooses topics and narrowed them. This stage, helps her in generating her ideas in writing.

b. Planning (outlining)

In this step, the writer organizes her ideas.

c. Writing and revising draft.

It is time to write and revise several drafts.

d. Writing the final copy.

This is the final step in writing. Be sure that as a writer you make all the corrections that you note on your second draft.
Moreover, Linse (2003:105) states that there are five steps in writing:

\section{a. Prewriting}

This activity is a simple as a drawing activity.

b. Writing

It is to get thoughts and ideas down on the paper.

c. Revising

It occurs when a writer looks for feedback from a teacher or another student.

d. Editing

In this step the teacher corrects the student's errors in spelling, grammar and punctuation.

\section{e. Publishing}

It refers to put all the writing in a final format where it can be shared with others.

\section{Descriptive paragraph}

Nugroho, et all (2010) gives some details information about descriptive paragraph.

a. Descriptive paragraph is a paragraph which tells about person or thing like. The purpose of this paragraph is to describe and reveal a particular person, place or thing. It means that the writer expose detail about something or someone.

b. Generic structure of this paragraph are:

1. Identification; identifying the phenomenon to be described

2. Description; describing the phenomenon in parts, qualities, and characteristics

c. Language features are;

1. Using attributive and identifying process 
2. Using adjective and classifiers in nominal group.

\section{Errors}

Gerot and Wignel (1994) categorize types of errors:

a. Interlingua errors. It takes place, because a learner is interference by her native language in which her linguistics system of second language is familiar.

b. Interlingua or developmental errors. According to Corder (1973:277) errors categories into four main categories: omission of some requirement elements, addition of some unnecessary or incorrect elements, selection of an incorrect element, and misplacement of element.

1. Omission

Certain linguistic forms may be omitted by the learners because of their complexity in production.

2. Addition

Learners not only omit elements but also add unnecessary element in sentences.

3. Selection

Adjective clause errors occur as a result of the selection of incorrect relative pronouns (who, whom, which, whose, and that)

4. Misplacement

Learners often misplace the relative pronoun to the correct position in the sentence.

\section{III.Method of the Research}

\section{A. Type of The research}

The research is descriptive research. This research was designed to find out the types of adjective clause errors made by the students in writing descriptive paragraph

\section{B. Population.}

Population of this research was students who take writing I in academic 2014/2015.

\section{Sample}

There were 39 students in class 2014 C English department of STKIP PGRI West Sumatera

\section{Instrument}

Researcher used writing test. The topics are about describing person and thing.

\section{E. Technique of data collection}

The researcher used writing test. It was essay test. Students are asked to choose one of four topics. They are given 60 minutes to write 1-3 descriptive paragraphs.

\section{F. Technique of data analysis}

The researcher analysed types of students errors in using adjective clause which constructed by the students in writing descriptive paragraph. There are four types of adjective clause:

a. Replacements of Subject (RS)

b. Replacements of Object of Verb (ROV)

c. Replacements of Object of Preposition (ROP)

d. Replacements of Possessive (RP)

\section{IV.Discussion of the finding}

The researcher interpreted the types of errors made by the students. She classified types of errors. They are omission, selection, misplacement, and addition.

1. Errors in using adjective clause as replacement of subject.

a. Omission. The students omitted the use of relative pronoun (which, who, that) which must be used in 
the adjective clause. The existing of errors here because the students do not have complete application of certain rules of L2

b. Addition. The students made or added redundant for subject in second sentence of adjective clause.

c. Selection. The students miss in selecting the relative pronouns (who, which, and that). The errors are the same as wrong concept of hypothesis which the students had.

d. Misplacement. These errors appeared because the students placed relative pronoun into incorrect place. It called as Interlingua errors. Here, the students interference by their native language.

2. Errors in using adjective clause as replacement of object of verb.

a. Omission. Almost all of the students error in placing relative pronouns into adjective clause. They omitted the use of relative pronoun (which, who or that) in the sentence.

b. Addition. The students made or added redundant for subject in second sentence of adjective clause.

c. Selection. The students miss in selecting the relative pronouns aweh onewdiate, andwtorto. doneceproms hypothesis which the students had.

d. Misplacement. These errors appeared because the students placed relative pronoun into incorrect place. It called as
Interlingua errors. Here, the students interference by their native language.

3. Errors in using adjective clause as replacements object of preposition. Students also errors the same as the case in errors in using adjective clause as replacement of object of verb. They were misplacement, addition, omission, and selection.

4. Errors in using adjective clause as replacements of possessive. Here, the students' errors in three aspects. They were omission, selection, and addition

\section{Conclusion and Suggestion}

\section{Conclusion}

Based on the finding above, it can be concluded that the students make errors in using adjective clause categorized into omission, selection, addition and misplacement. Then it is also assumed that the learners know about the relative pronoun, but they can not decide them correctly.

\section{Suggestion}

It is hope to the lecturers or teachers to give more attention to the students about the use of adjective clause and apply them in order to make the students familiar with adjective clause.

\section{REFERENCES}

[1] Alhaisoni, E. (2012) Language learning strategiey use of Saudi EFL students in an intensive learning context. Asian Social Science, 8:13 115-127.

[2] Celce Murcia (2006): Strategies to Engage the Mind of Learner. New York: Routledge

[3] Gerot and Wignel (1994) : Making Sense of Functional grammar.

[4] Sydney:Carditheb2005) Practical English language Teaching. New York: Mc Graw Hills Companies, Inc

[5] Nunan David (2000) Language Teaching Methodology; A Text Book for Teacher.London: Pearson Edducation

[6] Nugroho, Taufik and Hafrizo (2010) Introduction to Genre Based Approach. Jakarta: Ministry of national Education. Director General of Quality Improvement of Teacher and Education

[7] Oshima Alice and Houge, Ann (1991) Writing Academic English. New York: Addison-Wesley Longman FLEXChip Signal Processor (MC68175/D), Motorola, 1996. 
[8] Walter F Scot (2000) Basic Paragraph Structure Retrieved on February 2012. http://Irs.ed.uiuc.edu/students/fwalters/para.html A. Karnik, "Performance of TCP congestion control with rate feedback: TCP/ABR and rate adaptive TCP/IP," M. Eng. thesis, Indian Institute of Science, Bangalore, India, Jan. 1999.

[9] Werner K Patricia (1951) Mosaic A Content Based Grammar. Canada: Random House 